\title{
TITLE:
}

\section{PUERULUS ANGULATUS FROM THE WATERS OF KII PENINSULA, JAPAN}

AUTHOR(S):

Harada, Eiji

CITATION:

Harada, Eiji. PUERULUS ANGULATUS FROM THE WATERS OF KII

PENINSULA, JAPAN. PUBLICATIONS OF THE SETO MARINE BIOLOGICAL LABORATORY 1980, 25(1-4): 243-251

\section{ISSUE DATE:}

1980-02-29

URL:

http://hdl.handle.net/2433/175982

RIGHT: 


\title{
PUERULUS ANGULATUS FROM THE WATERS OF KII PENINSULA, JAPAN ${ }^{1}$ )
}

\author{
EIJi HARADA \\ Seto Marine Biological Laboratory \\ With Text-figures $1-2$ and Table 1
}

Through a series of works by the late Professor I. Kubo (1939, 1954, 1955, 1963a, b), most of the palinurid lobsters of the Japanese waters have been examined and described, some as new species, to attain to a comprehensive view of the group in Japan. Included in these are the species of the genera of Panulirus, Justitia, Puerulus and Palinustus, numbering 8, 1, and 1 species respectively (see also Harada, 1969a, b), some of which were considered at that time to be extremely rare in the Japanese waters.

Among the specimens stored in the Seto Marine Biological Laboratory are two specimens of "Puerulus gracilis Kubo", said to be identified by the late Professor I. Kubo himself, one of which came from Kumano-nada off the east coast of Kii Peninsula and the other from the water off Minabe on the west coast. The date of collection of the former specimen goes back to 1934. The description of Puerulus gracilis was originally given by Kubo (1939), based on the specimens collected off Kominato of Boso Peninsula, east to Tokyo, but this species was later synonymized to Puerulus angulatus (Bate, 1888) by Holthuis (1966). Nevertheless, our knowledge on this species in the Japanese waters has been confined to the statements of Kubo's paper concerned.

Recently, in March 1976, several live specimens of this species were caught by the trammels operated by the Marinarium of Taiji Whale Museum off Tomyo-zaki on the southeast coast of Kii Peninsula, and were identified by Dr. K. Hayashi of the Shimonoseki University of Fisheries. In March of the following years, they fished the trammels at the same locality and captured more than ten specimens alive each year. This indicates that the species is not so much rare on some particular bottom as has been regarded.

In the present paper, the descriptions are given for these specimens of Puerulus angulatus from the waters of Kii Peninsula, and they are compared with the previous descriptions.

I wish to express my thanks to Mr. F. Yanagisawa of the Taiji Whale Museum for affording me the specimens stored at their specimen room for examination. I am particularly grateful to Dr. Isabella Gordon of the British Museum (Natural History) for allowing me to examine the specimens of palinurid and scyllarid lobsters retained at

1) Contributions from the Seto Marine Biological Laboratory, No. 658.

Publ. Seto Mar. Biol. Lab., XXV (1/4), 243-251, 1980.

(Article 16) 
their Museum in 1960 and sending me two specimens of Puerulus sewelli Ramadan 1938, that made the present closer comparison possible.

\author{
Puerulus angulatus (Bate, 1888)
}

(Japanese name: Gusoku-ebi, Kubo, 1939)

Panulirus angulatus Bate, 1888, Rep. Voy. Challenger, Zool., Vol. 24, p. 81, Pl. 11, figs. 2-4.

Puerulus angulatus Calman, 1909, Ann. Mag. Nat. Hist., Ser. 8, Vol. 3, p. 442.

Puerulus carinatus Borradaile, 1910, Trans. Linn. Soc. London, Zool., Ser. 2, Vol. 13, p. 261, Pl. 16, fig. 5.

Puerulus angulatus Balss, 1925, Wiss. Ergebn. Valdivia Exped., Vol. 20, p. 203.

Puerulus carinatus Ramadan, 1938, John Murray Exped. Sci. Rep., Vol. 5, p. 133, figs. 6-7.

Puerulus gracilis Kubo, 1939, Bull. Jap. Soc. Sci. Fish., Vol. 7, p. 316, figs. 1-2.

Puerulus angulatus Holthuis, 1966, Proc. Symp. Crust. Ernakulam, Part I, Symp. Ser. 2, p. 267.

non Puerulus angulatus de Man, 1916, Siboga-Exped., Monogr. 39a², p. 36, P1. 2, fig. 5.

Materials Examined.

1 ㅇ, c.l. $38.2 \mathrm{~mm}$, Seto Marine Biological Laboratory Specimen Macr.-56, Kumanonada, off east Kii Peninsula, 150 fms, July 1934.

1 오, c.l. $18.9 \mathrm{~mm}$, Seto Marine Biological Laboratory Specimen Macr.-48, off Minabe, west Kii Peninsula, $100 \mathrm{fms}$, March 1944.

3 우, c.l. $49.9-52.2 \mathrm{~mm}, 8$ 沾, c.l. $34.0-53.0 \mathrm{~mm}$, specimens from the Marinarium of Taiji Whale Museum, off Tomyo-zaki, Taiji, south-east Kii Peninsula, 300-400 $\mathrm{m}$, March 1977-1979.

Description. Morphological features of the body and appendages and their spinulation well agree with those described by Bate (1888), Kubo (1939) and Holthuis (1966).

The carapace is distinctly shorter than the abdomen, the abdomen without the telson being mostly 1.3-1.4 times as long as the carapace. The region before the cervical groove is a little shorter than the region behind the cervical groove, the latter being 1.1-1.3 times as long as the former on the dorsal median line.

The supra-orbital horns are strong, curved and directed forward, followed by a row of decreasing 3 teeth, the smallest last of which being of the size of a spinule. The anterodorsal margin of the carapace is furnished usually with a pair of sharp spines, rarely 2-pointed, near the inner bases of the supra-orbital horns. The lower orbital spines are strong, followed by a row of 2 spines and 1 spinule, and below them 1 broad tooth, rarely 2-pointed, is present on the anterolateral edge of the carapace. The post-orbital spines are absent. A pair of rows of 4-5 spines and numerous spinules, arranged closely together anteriorly and leaving the shallow median furrow in between posteriorly just before the cervical groove, are present in the gastric region of the carapace. An upper row of spines and a lower row of spinules are present between the row of teeth behind the supra-orbital horn and the row of spines behind the strong infra-orbital spine. The median carina of the carapace behind the cervical groove bears 3 anterior large and 2-3 posterior small teeth. The dorsolateral angular ridges of the carapace behind the cervical groove are distinct and are furnished with a branchial row of spines and additional numerous spinules. The anterolateral margin 
of the post-cervical part of the carapace is furnished partly with sharp spines just behind the cervical groove.

The abdominal median carina is present on the tergites of the abdominal segments I-V. The median carina on the 1st abdominal tergite is restricted to its posterior

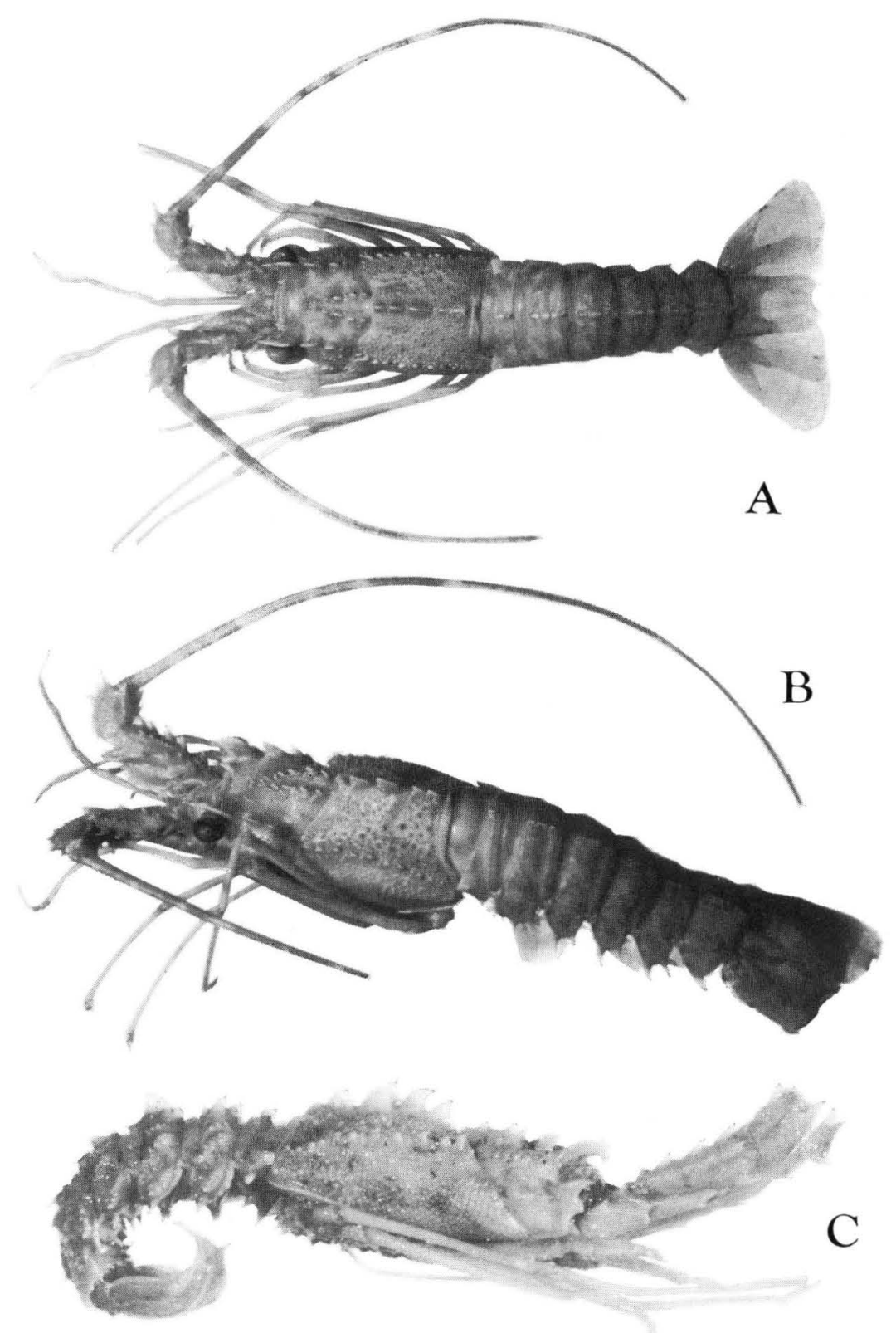

Text-fig. 1. Puerulus angulatus (Bate, 1888). A: dorsal view of a male specimen, c.l. $44.4 \mathrm{~mm}$, from off Tomyo-zaki. B: oblique view of a female specimen, c.1. $51.0 \mathrm{~mm}$, from off Tomyozaki. C: lateral view of a young female specimen, c.l. $8.8 \mathrm{~mm}$, from off Minabe. 

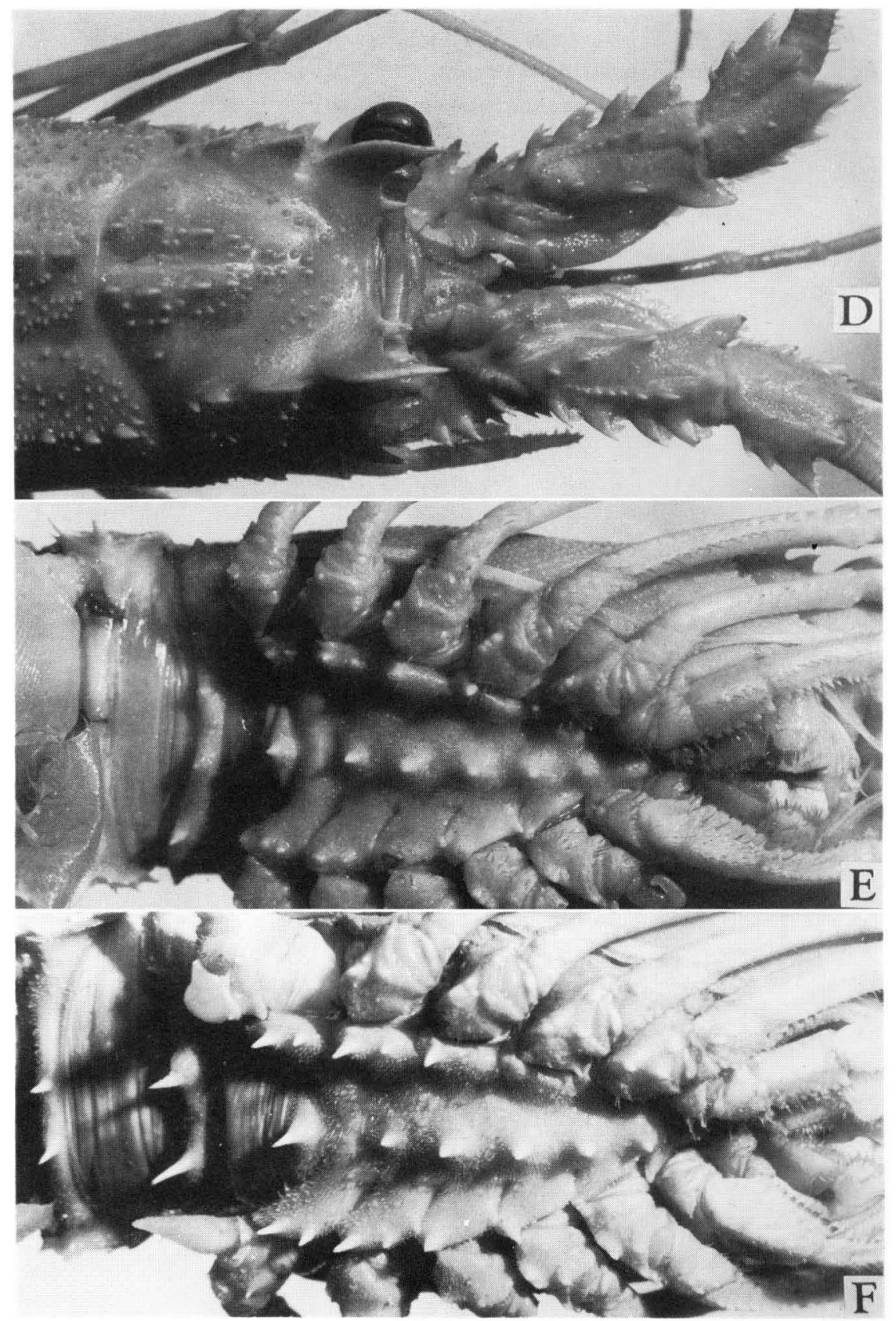

Text-fig. 2. Puerulus angulatus (Bate, 1888). D: dorsal view of the anterior part of the body of a female specimen, c.l. $41.0 \mathrm{~mm}$, from off Tomyo-zaki. E: oblique view of the thoracic sternum of the same specimen. F: oblique view of the thoracic sternum of a male specimen, c.1. $53.0 \mathrm{~mm}$, from off Tomyo-zaki. 
marginal part behind the transverse furrow and is crested with 1-2 knobs. The median carinae on the $2 \mathrm{nd}-5$ th abdominal tergites run behind the anterior transverse furrow and are interrupted by the posterior transverse furrow and further by two incisions into 4 knobs in the abdominal segment II or by one incision into 3 knobs in the abdominal segments III-V. The middle knob projects posteriorly into a sharp short spine in the abdominal segments IV-V in some specimens and in the abdominal segment $\mathrm{V}$ the posterior knob is usually also protruded posteriorly into a sharp short spine. Three oblique tuberculate low ridges are present on the lateral surface of the 2nd-5th abdominal tergites. A pair of submedian ridges are present on the 6 th abdominal tergite, each bearing 4-6 spinules. A single small median spine and a pair of lateral spines, directing posteriorly, are present on the posterior margin of the 6 th abdominal tergite. A pair of anterior submedian spines and a pair of diverging posterior rows of spines are present on the dorsal surface of the telson, and its lateral margin bears 1 middle and 1 terminal spine.

The pleuron of the abdominal segment $I$ ends in a short spinous process. The pleura of the abdominal segments II-V terminate forked into two long sharp spinous processes, that are nearly of same size in all the segments. The pleuron of the abdominal segment VI ends in a broad spinous process, with a spine medially on its posterior margin. The anterior margin of the pleuron of the abdominal segment II bears 2-3 small spinules.

The antennular plate bears on its dorsal surface a pair of anteriorly convergent rows of spinules, anterior one or two of which are distinctly stronger in male. The epistome terminates anteriorly into a strong median spine and is incised with a median groove posteriorly.

The thoracic sternum is armed with 1 strong spine on the median boss in each of all 8 thoracic segments, which is diminished and rounded in some specimens, mostly females. The lateral ridge of the thoracic sternite bears 1 strong spine in the thoracic segments V-VI and 2 strong spines in the thoracic segments VII-VIII. These spines are generally blunt and less prominent in female.

Two pairs of strong spines are present on the posterior margin of the 1st abdominal sternite, which are weak in female. A pair of strong spines are present in male on the posterior margin of the sternite in the abdominal segments II-V, but are absent in female. Two pairs of posteriorly directed strong submedian spines are present on the posterior margin of the 6 th abdominal sternite. In male, additional one pair or two of spines are present laterally on the posterior margin of this sternite and two pairs of spines medially on its ventral surface.

The eyes are longer than broad, and their peduncles are constricted slightly behind the corneas. The ultimate segment of the antennular peduncle is slightly shorter than the flagellum, slightly longer than the penultimate segment, and slightly shorter than the half length of the third segment. The ultimate segment of the antennal peduncle has 3 marginal teeth (including the terminal one) on both its medial (adaxial) and lateral (abaxial) sides and 1 dorsal and 1 ventral spine on its anterior (distal) margin, and several spinules on its dorsal surface. The penultimate segment is fur- 
Table 1. Measurements of the specimens.

\begin{tabular}{|c|c|c|c|c|c|c|c|c|c|c|c|c|}
\hline \multirow{2}{*}{ sex } & \multicolumn{3}{|c|}{ carapace } & \multicolumn{2}{|c|}{$\begin{array}{c}\text { abdomen } \\
\text { length }(\mathrm{mm})\end{array}$} & \multicolumn{2}{|c|}{$\begin{array}{c}\text { peduncle } \\
\text { length }(\mathrm{mm})\end{array}$} & \multicolumn{5}{|c|}{$\begin{array}{l}\text { pereiopod } \\
\text { length }(\mathrm{mm})\end{array}$} \\
\hline & $\begin{array}{l}\text { length } \\
(\mathrm{mm})\end{array}$ & $\begin{array}{l}\text { hepatic/gastric } \\
\text { ratio }\end{array}$ & $\begin{array}{l}\text { Wlath } \\
(\mathrm{mm})\end{array}$ & segments & telson & antennule & antenna & 1st & 2nd & $3 \mathrm{rd}$ & 4th & 5 th \\
\hline \multicolumn{13}{|c|}{ Kumano-nada, VII-1934. } \\
\hline & 38.3 & 1.26 & 24.3 & 50.0 & 20.5 & 32.0 & 31.1 & 32.4 & 40.0 & - & - & - \\
\hline \multicolumn{13}{|c|}{ Off Minabe, II-1944. } \\
\hline & 18. 9 & 1.15 & 10.8 & 20.2 & 9.5 & 12.6 & 15.2 & 17.5 & 19. 8 & 24.5 & 33.2 & - \\
\hline \multicolumn{13}{|c|}{ Off Tomyo-zaki, III8-1977/1979. } \\
\hline & 34.0 & 1.30 & 22.9 & 44.5 & 19.3 & 31.0 & 28.1 & 35.2 & 45.5 & 59.2 & 76.0 & 81.0 \\
\hline & 37.8 & 1.29 & 27.0 & 50.0 & 20.3 & 35.7 & 29.9 & - & - & - & - & - \\
\hline & 39.9 & 1. 24 & 26.4 & 53.2 & 21.2 & 36.6 & 32.0 & 41.2 & 51.4 & 66.9 & - & - \\
\hline & 40.8 & 1.24 & 26.3 & 53. 8 & 20.3 & 35.2 & 32.2 & 44. 1 & 53.6 & 68.6 & 87.5 & 97.0 \\
\hline & 44.4 & 1.28 & 29.5 & 57.7 & 23. 3 & 43.0 & 33.0 & 48.6 & 60.3 & 78.0 & 96.8 & 111.3 \\
\hline & 45.5 & 1. 30 & 31.5 & 61.3 & 24.8 & 43. 6 & 34.8 & 50.2 & 61.1 & 77.8 & 102.3 & - \\
\hline & 45.6 & 1. 26 & 29.6 & 58.4 & 24.0 & 41.4 & 36.4 & 47.2 & - & - & - & - \\
\hline & 53.0 & 1.21 & 36.5 & 72.9 & 28.7 & 50.5 & 42.9 & 61.5 & 74.2 & - & - & - \\
\hline & 49.9 & 1.12 & 33.3 & 64.4 & 26. 6 & 42.9 & 37.8 & 55.7 & 66.9 & 79.9 & 77. $5^{*}$ & - \\
\hline & .51 .0 & 1.17 & 35.2 & 68.9 & 27.7 & 46.2 & 38.3 & 51.2 & 67.8 & - & 106.0 & 105.6 \\
\hline & 52.2 & 1.21 & 36.1 & 70.1 & 28.2 & 43.1 & 40.3 & 56.2 & 69.0 & 85.2 & 107.0 & - \\
\hline
\end{tabular}

* The propodus is abnormally short. 
nished with 4 teeth on its lateral margin, 1 large terminal tooth on its antero-medial corner, followed by 3-5 spines on the dorsal surface, a row of 5-7 spines on its dorsal surface laterally, 2 spines on the anteroventral margin, the lateral one of which is followed by a row of 4 spines, and a row of spinules on its ventral surface. The distal third segment is expanded into a flattened lobe along its medial margin anteriorly before the stridulating process, and is armed with 2 spines on its dorsal anterior margin, a row 3-4 spinules along its ventral anterior margin, 1 spine near the anterior tip and 1 spine near the posterior base on its ventral surface, and 2 teeth and 1-2 spines on the posterior half of its lateral margin.

The 3rd-5th pereiopods are distinctly slenderer than the 1 st and 2 nd. The 5 th is the longest in male, while the 4 th is longer than or subequal to the 5 th in male. A longitudinal row of spinules are present along the ventral ridge of the merus in the 3rd maxillipeds and the 1st and 2nd pereiopods. One terminal spine is present on the dorsal side of the distal end of the merus in all the pereiopods. The 5 th pereiopods are chelate in female. The fleshy protrusion at the base of the coxa of the 5 th pereiopod, carrying the genital opening, is present in male. The 1st pleopods are absent in the abdominal segment $\mathrm{I}$. The endopods are absent in male in the pleopods of the abdominal segments II-V.

The measurements of various parts of the specimens are given in Table 1.

Body colour in the specimens which retain well the living state of colouration is generally pale yellowish orange with darker reddish spots scattered over the dorsal surface of the carapace at the bases of teeth, spines and spinules and with darker reddish bands on abdominal tergites. The antennal flagella have alternating wide and narrow white bands.

Remarks. Most of the specimens treated in the present study are much larger than the specimens examined by Kubo (1939) and are similar in carapace length with the specimens of Holthuis (1966). The smallest specimen in the present materials is similar in carapace length with the type specimen of Bate (1888) and slightly larger than the juvenile of Holthuis (1966). This smallest specimen from off Minabe resembles quite well with the Bate's specimen in appearance and its spinulation is distinctly relatively stronger than in the larger specimens.

The present specimens differ from those of the previous descriptions only in minor characters. Kubo (1939) describes his specimens as having "two or three knobs" on the median carina of the 1st abdominal tergite, but there is no specimen carrying 3 knobs on this part in the present materials. Holthuis (1966) gives the descriptions for the Philippine specimens that in female the anterior spinous process of the pleuron in the 2nd-5th abdominal segments "usually is longer than the posterior, especially so in the second somite," but this character is not apparently recognizable in the present materials. Holthuis writes on the spinulation on the antennular plate in the juvenile that "these spines and spinules may be indistinct," but two rows of spinules are distinctly seen on the antennular plate of the present smallest specimen.

Ramadan (1938), in his descriptions of Puerulus sewelli and Puerulus carinatus from the Indian Ocean, gives the measurements of the specimens of Puerulus angulatus, in 
which he includes the measurements of Bate's type specimen, and has compared these three species. The relative lengths of the carapace, the abdomen without the telson, and the telson, read from his measurements given, agree well with those of the present specimens. He does not, however, present anywhere the derivations of his specimens of Puerulus angulatus other than Bate's type specimen.

The validness of Puerulus carinatus as a separate species is doubted by Holthuis (1966), who regards Ramadan's specimen as representing the characteristics of Puerulus angulatus and considers Puerulus carinatus as a synonym of Puerulus angulatus. The specimen of Puerulus carinatus from John Murray Expedition Station 105, according to my notes of examination and photographs taken at the British Museum (Natural History) in 1960, shows good agreement in general spinulation with the present specimens, but the spines on the thoracic sternum are very much reduced and the supraorbital horns are shorter and broader, as in Puerulus sewelii, than in the present specimens.

The similarity of the present specimens to those described in the previous papers are remarkable, and synonymization made by Holthuis (1966) of Puerulus gracilis Kubo 1939 and Puerulus carinatus Borradaile 1910 to Puerulus angulatus (Bate, 1888) is justifiable.

\section{REFERENCES}

Balss, H. 1925. Macrura der Deutschen Tiefsee-Expedition. I. Palinura, Astacura und Thalassinidea. Wiss. Ergebn. Valdivia Exped., 20: 185-216.

Bate, G.S. 1888. Report on the Crustacea Macrura collected by H.M.S. Challenger during the years 1873-86. Rep. Voy. Challenger, Zool., 24: i-kc, 1-942.

Borradaile, L.A. 1910. Penaeidea, Stenopidea, and Reptantia from the western Indian Ocean. The Percy Sladen Trust Expedition of the Indian Ocean in 1905, under the leadership of Mr. J. Stanley Gardiner. Trans. Linn. Soc. London, Zool., Ser. 2, 13: 257-264.

Calman, W.T. 1909. The genus Puerulus Ortmann and the postlarval development of the spiny lobsters (Palinuridae). Ann. Mag. Nat. Hist., Ser. 8, 3: 441-446.

Harada, E. 1965. Zoogeographical aspects of Palinura found in the Kii District. Nankiseibutu, 7(2): 35-42. (in Japanese)

1966. Supplement to zoogeographical aspects of Palinura found in the Kii District. Ibid., 8(1): 17-18. (in Japanese)

Holthuis, L.B. 1946. The Stenopodidae, Nephropsidae, Scyllaridae and Palinuridae. The Decapoda Macrura of the Snellius Expedition. I. Biological results of the Snellius Expedition. XIV. Temminckia, $7:$ 1-178.

1963. Preliminary descriptions of some new species of Palinuridea (Crustacea Decapoda, Macrura Reptantia). Proc. Kon. Nederl. Akad. Wetensch., Ser. C, 66(1): 54-60.

1966. On spiny lobsters of the genera Palinurellus, Linuparus and Puerulus (Crustacea Decapoda, Palinuridae). Proc. Symp. Crustacea, Ernakulam, 1965, Part I, Symposium Ser. 2: 260-278.

Kubo, I. 1939. A new spiny lobster, Puerulus gracilis. Bull. Japan. Soc. Sci. Fish., 7(6) : 316-318.

1954. Systematic studies on the Japanese macrurous decapod Crustacea. 3. On the palinurid lobsters. Journ. Tokyo Univ. Fish., 41(1): 95-105.

1955. Systematic studies on the Japanese macrurous decapod Crustacea. 5. A new palinurid, Nupalirus japonicus, gen. et sp. nov. Ibid., 41(2): 185-188.

1963. Systematic studies on the Japanese macrurous decapod Crustacea. 6. A new and an imperfectly known species of palinurid lobster. Ibid., 49(1): 63-71.

- 1963. Two rare species of palinurid lobster. Researches on Crustacea, Carcinol. Soc. Japan, $1:$ 3-11. (in Japanese) 
Man, J.G.de. 1916. The Decapoda of the Siboga Expedition. Part III. Families Eryonidae, Palinuridae, Scyllaridae and Nephropsidae. Siboga-Exped., Monogr. 39a $a^{2}: 1-122$.

Ortmann, A. 1891. Die Abtheilungen der Reptantia Boas: Homaridea, Loricata und Thalassinidea. Die Decapoden-Krebse des Strassburger Museums, mit besonderer Berücksichitgung der von Herrn Dr. Döderlein bei Japan und den Liu-Kiu-Inseln gesammelten und z.Z. im Strassburger aufbewahrten Formen. III Theil. Zool. Jb. Syst., 6: 1-58.

1897. On a new species of the palinurid genus Linuparus found in the upper Cretaceous of Dakota. Amer. Journ. Sci., Ser. 4, 4: 290-297.

Ramadan, M. 1938. The Astacura and Palinura. Sci. Rep. John Murray Exped., 5(5): 123-145. 